Jurnal Biologi dan Pembelajarannya, Vol 7 No 2, Oktober 2020. Pp: 8-14

e-ISSN: $2406-8659$

\title{
Strategi Pemberdayaan Peternak Sapi Bali Akibat Pandemi Covid-19 di Desa Tiga, Kecamatan Susut, Kabupaten Bangli, Provinsi Bali
}

\author{
Ardina Tanjungsari \\ Program Studi Peternakan, Fakultas Ilmu Kesehatan dan Sains, Universitas Nusantara PGRI Kediri \\ Jl. Mdr, Kasian, Manyaran, Kec. Banyakan, Kediri, Jawa Timur \\ Email : ardina.tanjungs@gmail.com
}

\begin{abstract}
Abstrak
Pandemi Covid-19 berdampak terhadap eksistensi perkonomian, salah satu dampaknya adalah terganggunya produksi ternak di seluruh daerah tidak terkecuali di Desa Tiga, Kecamatan Susust, Kabupaten Bangli, Provinsi Bali. Lokasi Desa Tiga terletak di kaki Gunung Batur dengan ketinggian sekitar \pm 800 meter dari permukaan laut. Penduduk Desa Tiga banyak yang bermata pencaharian sebagai peternak sapi Bali dengan metode beternak tradisional dan belum banyak mendapatkan pengaruh modern. Tujuan penelitian ini adalah untuk mengetahui faktor-faktor strategi pemberdayaan peternak Sapi Bali di Desa Tiga, Kabupaten Bangli, Provinsi Bali akibat pandemi Covid-19. Penelitian ini menggunakan metode simple random sampling. Penelitian dilakukan terhadap 20 peternak yang rata-rata memiliki 2-15 ekor sapi Bali. Analisis data menggunakan analisis deskriptif. Kesimpulan dari penelitian ini menunjukkan bahwa pandemi Covid-19 tidak berpengaruh secara signifikan pada sosial-ekonomi peternak sapi Bali di Desa Tiga. Strategi pemberdayaan bagi peternak perlu adanya edukasi tentang bahaya virus dan protokol kesehatan untuk pencegahan penularan virus Covid-19. Pemerintah Provinsi Bali sebaiknya lebih memperhatikan kesejahteraan peternak, seperti dilakukannya edukasi mengenai kawin suntik atau inseminasi buatan, vaksin gratis, perawatan kandang sesuai standar, jenis pakan hijauan dan kosentrat yang cocok untuk sapi Bali, dan penyediaan rumah potong hewan di Kabupaten Bangli. Kerja sama yang baik antara peternak dan pemerintah Provinsi Bali diharapkan menjadi salah satu langkah konservasi dan perbaikan mutu genetik sapi Bali, sehingga menciptakan kesejahteraan peternak yang terintegrasi dan berkelanjutan.
\end{abstract}

Kata kunci : Bangli, Covid-19, keberlanjutan, peternak, sapi Bali

\section{PENDAHULUAN}

Pandemi Covid-19 telah merubah tatanan dunia secara dramatis dan masif dan pada akhirnya berimbas kepada seluruh sektor. Akibat pandemi, sektor peternakan hanya tumbuh 2,86\% melambat dari Q1 2019 yang tumbuh $7,96 \%$. Pemenuhan kebutuhan daging sapi pun selalu terdapat kesenjangan yang luar biasa. Kebutuhan daging nasional sebesar 650.000 ton per tahun atau setara 3,8-3,9 juta ekor, hal ini tidak dapat dipenuhi karena jumlah populasi sapi potong hingga tahun 2019 hanya sebanyak 17.118.650 ekor. Ketidakmampuan produksi lokal memenuhi kebutuhan daging nasional, sehingga perlu dilakukan sebuah gagasan baru yang relevan dengan kondisi saat ini. Hal pertama yang dapat dilakukan yaitu mengubah arah pembangunan peternakan yang terstruktur, sustainable, serta partisipatif aktif semua stakeholder untuk lebih menekankan permberdayaan dan perlindungan peternak lokal [1].

Indonesia memiliki kekayaan keanekaragaman (biodiversitas) plasma nutfah satwa Nusantara, khususnya ternak, yang cukup tinggi merupakan anugerah Tuhan Yang Maha Kuasa yang patut disyukuri dan dibanggakan, selain itu juga harus dijaga kelestariannya serta dioptimalkan pemanfaatannya bagi generasi penerus bangsa Indonesia secara berkelanjutan. Sejumlah puluhan rumpun ternak asli Indonesia dan ratusan rumpun ternak yang telah teradaptasi dengan kondisi lokal Indonesia adalah potensi yang dapat dimanfaatkan sebagai penyedia bahan baku pangan dan bahan baku industri di Indonesia. Tujuan dari konservasi secara garis besar yaitu pemanfaatan, dan pengembangan berkelanjutan terhadap plasma nutfah satwa kawasan untuk pangan dan pertanian, ketahanan pangan, peningkatan status kesehatan dan gizi manusia, pengembangan masyarakat pedesaan, dan pelestarian biodiversitas satwa [2].

Peran penting sub sektor peternakan dalam pembangunan sektor pertanian sangat diperlukan, yaitu membantu pemantapan ketahanan pangan untuk memenuhi kebutuhan protein hewani, pemberdayaan ekonomi masyarakat, dan dapat memacu pengembangan wilayah [3].

Menurut Keputusan Menteri Pertanian Nomor 325/Kpts/OT.140/1/2010 menetapkan sapi Bali sebagai rumpun asli Indonesia. Sapi Bali merupakan sapi hasil domestikasi dari banteng asli Indonesia yang mempunyai keunggulan dalam daya reproduksi, daya adaptasi dan persentase karkas yang tinggi. Pemerintah mulai melirik sapi bali sebagai sapi lokal unggulan. Kebutuhan komoditas pangan terutama daging sapi ini belum dapat dipenuhi dalam negeri sehingga impor daging sapi atau sapi masih dilakukan, tetapi tahun ini Kementerian 
Pertanian (Kementan) mengungkapkan impor sapi Indonesia menurun [4]. Hal ini memberikan peluang besar bagi peternak sapi lokal untuk meningkatkan produksi untuk memenuhi kebutuhan komoditas pangan dalam negeri.

Salah satu bentuk usaha peternakan yang memiliki potensi besar untuk dikembangkan yaitu ternak sapi potong. Usaha ternak sapi potong dapat dikategorikan berhasil bila telah memberikan kontribusi pendapatan dan dapat memenuhi kebutuhan hidup peternak sehari-hari, hal ini dapat dilihat dari berkembangnya jumlah kepemilikan ternak, pertumbuhan berat badan ternak dan tambahan pendapatan rumah tangga. Pengelolaan dan pemeliharaan sapi potong adalah salah satu cara untuk meningkatkan pendapatan rumah tangga [5]. Sementara itu, dampak pandemi virus Corona atau Covid-19 berdampak pada semua sektor perekonomian tidak terkecuali pada usaha ternak sapi potong.

Pemerintah Provinsi Bali berencana untuk mengembangkan Kabupaten Bangli sebagai sentra baru peternakan sapi Bali. Sebab, wilayah Bangli terletak di dataran tinggi Gunung Batur didukung cuaca yang sejuk sehingga cocok untuk pengembangan peternakan. Bangli memiliki program "Gita Santi" yang bertujuan untuk pemberdayaan masyarakat desa, khususnya bidang ekonomi, pendidikan, kesehatan, dan lingkungan. Populasi sapi Bali saat ini sudah meningkat dari 478 ribu ekor pada 2013 menjadi 533 ribu ekor pada akhir 2014. Bali memiliki daya tampung untuk populasi sapi hingga 700 ribu ekor. Langkah konkrit untuk mendukung swasembada sapi nasional, Bali akan terus meningkatkan populasi sapinya. Salah satu caranya dengan menggandeng masyarakat setempat mengembangkan pola pembibitan rakyat [6].

Desa Tiga yang posisinya berada di ujung selatan dan berbatasan dengan Kecamatan Bangli. Desa ini termasuk dalam salah satu desa adat yang berbatasan langsung dengan Desa Kayubihi dan Desa Tradisional Penglipuran. Secara geografis wilayah Desa Tiga berada di ketinggian \pm 800 meter dari permukaan air laut. Desa Tiga memiliki lokasi sangat sejuk dan tanah yang subur karena terletak di kaki Gunung Batur, sehingga mendukung sebagai calon sentra pembibitan sapi Bali [7]. Penduduk desa memiliki mata pencaharian beragam, mulai dari petani, peternak, pengrajin, dan sebagainya. Mata pencaharian sebagai peternak cukup banyak dilirik masyarakat karena dikenalkan secara turun-temurun dari nenek moyang. Populasi ternak sapi Bali di Kecamatan Susut, Bangli sudah mencapai 2500 ekor pada tahun 2008 dengan jumlah populasi sebesar itu rata-rata setiap harinya menghasilkan 10.000 liter urine sapi per hari dan 25 ton kotoran padat per hari. Jenis sapi yang dipilih adalah sapi Bali yang merupakan sapi lokal rumpun asli Indonesia yang harus dilestarikan [8]. Peranan usaha ternak sapi Bali di Desa Tiga, Kecamatan Susut, Kabupaten Bangli, Provinsi Bali dalam menumbuhkan perekonomian masyarakat pedesaan menjadi isu yang menarik untuk diidentifikasi.

\section{METODE PENELITIAN}

Penelitian dilakukan pada bulan Juli-Agustus 2020 di Desa Tiga, Kabupaten Bangli, Provinsi Bali, dengan menggunakan responden 20 peternak yang rata-rata memiliki 2-20 ekor sapi Bali. Parameter yang diamati meliputi: identitas responden, pemeliharaan sampai penjualan yang dilakukan sebelum dan saat terjadi pandemi Covid-19, dan harapan peternak kepada pemerintah Provinsi Bali.

Studi kasus dipilih sebagai metode penelitian, instrumen yang digunakan merupakan suatu penelitian dengan mengambil sampel dari suatu populasi untuk mendapatkan data baik primer maupun sekunder dengan kuisioner sebagai pengumpulan data primer [9]. Studi kasus dapat dilakukan kepada individu, kelompok, maupun komunitas untuk membantu menunjukkan hal-hal penting yang menjadi perhatian, proses sosial masyarakat dalam peristiwa yang konkret, pengalaman dan pemangku kepentingan. Kasus yang dimaksud dapat mengilustrasikan terjadinya masalah dapat diatasi melalui penelitian [10]. Data primer diperoleh dari simple random sampling dengan wawancara langsung kepada peternak lokal.

Pemilihan wilayah penelitian dilakukan secara purpossive sampling yang dilakukan berdasarkan pertimbangan tertentu [11]. Pertimbangan ini didasarkan pada salah satu Desa kategori sentra sapi Bali di Kecamatan Susut, Kabupaten Bangli yang lokasinya mudah diakses dan peternakannya masih tradisional. Desa Tiga dipilih karena wilayah Desa nya masih belum banyak tersentuh modernisasi dalam hal perawatan sapi, kemudian edukasi mengenai virus Covid-19 juga belum banyak dilakukan sehingga peneliti memilih sebagai lokasi penelitian.

Data yang diperoleh ditabulasi kemudian dihitung persentase atau rata- rata dan simpangan bakunya yang selanjutnya dianalisis secara diskriptif.

\section{HASIL DAN PEMBAHASAN}

Populasi sapi Bali di lokasi penelitian sekitar \pm 300 ekor yang dimiliki oleh 20 peternak. Usaha pertanian dan peternakan biasanya menjadi pilihan utama mata pencaharian oleh masyarakat desa. Sistem peternakan pemeliharaannya dilakukan secara tradisional dengan cara hewan ternak dikandangkan yang letaknya sebagian besar terdapat di tegal dan sawah, pakan yang diberikan rumput lapang, jerami jagung dan rumput gajah dengan 
sistem pemberian pakan cut and carry (setelah dipotong langsung diberikan) [12]. Lebih lanjut mengenai kelayakan sosial-ekonomi peternak sapi Bali di Desa Tiga perlu diketahui kelompok umur peternak, tingkat pendidikan peternak, pekerjaan utama peternak, pemberian pakan ternak, dan luas kandang ternak.

\section{Kelayakan Sosial-Ekonomi Peternak Sapi Bali di Desa Tiga}

a. Kelompok Umur Peternak

Kelompok umur peternak di Desa Tiga berusia 46-55 tahun sebanyak 50\%, peternak berusia $>55$ tahun sebanyak 30\%, dan peternak berusia 36-45 tahun sebanyak 20\%. Kelompok umur tersebut menunjukkan bahwa sebagian besar peternak menggeluti usaha peternak sapi potong adalah orang-orang yang berada dalam usia produktif. Hal ini penting untuk diketahui karena peternak pada kelompok umur tersebut masih memiliki kemampuan fisik yang kuat dan pemikiran yang matang terutama dalam mengelola usaha yang digelutinya.

Peternak di Desa Tiga rata-rata telah dilatih cara beternak secara turun-temurun oleh orang tua sejak Sekolah Dasar. Hal ini juga yang ditularkan peternak saat ini kepada anak dan cucu mereka sejak dini. Anak-anak sejak Sekolah Dasar dilatih untuk mencari pakan ternak di kebun atau ladang, hal ini dilakukan untuk melatih rasa tanggung jawab sebelum mereka memiliki ternak sendiri. Pengalaman beternak semakin lama diharapkan pengetahuan yang didapat semakin banyak sehingga ketrampilan dalam menjalankan usaha peternakan semakin meningkat dan produktif [13].

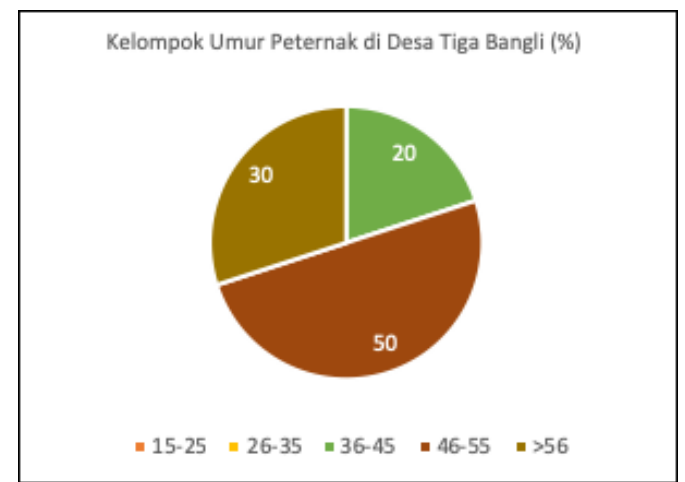

Gambar 1. Kelompok umur peternak di Desa Tiga, Kecamatan Bangli (\%)

b. Tingkat Pendidikan Peternak

Tingkat Pendidikan peternak di Desa Tiga sebanyak 65\% adalah SD (Sekolah Dasar), kemudian 15\% SMP (Sekolah Menengah Pertama), 10\% SMA (Sekolah Menengah Atas) dan 10\% tidak sekolah. Secara keseluruhan dapat dikatakan bahwa tingkat pendidikan peternak kurang untuk bekal mereka beternak, tetapi seluruh peternak telah mendapatkan pendidikan dasar yaitu membaca dan berhitung. Pendidikan sangat penting bagi peternak karena dengan pendidikan tinggi, peternak dapat dengan mudah memperoleh informasi dan inovasi terkait usaha sapi Bali yang digeluti. Diharapkan pada generasi berikutnya (anak dan cucu) dapat melanjutkan Pendidikan sampai tingkat perguruan tinggi, sehingga nantinya mereka dapat mengembangkan usaha ternak menjadi lebih baik dan dapat bekerja sama dengan masyarakat lebih luas lagi.

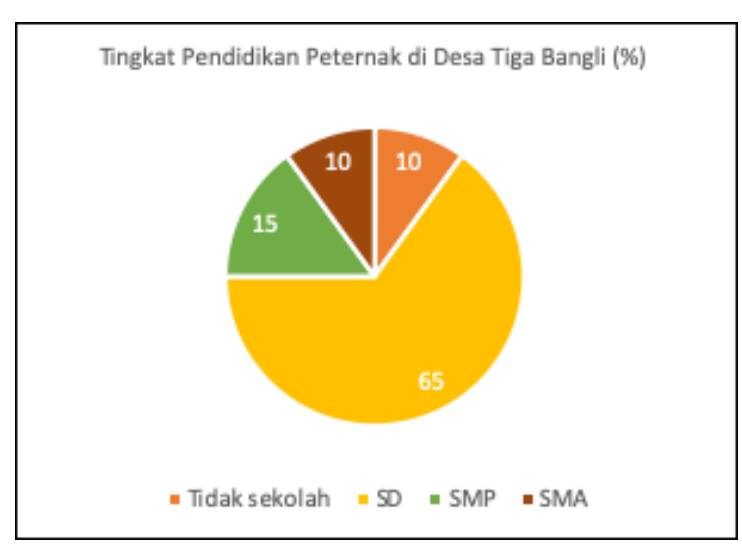

Gambar 2. Tingkat Pendidikan peternak di Desa Tiga, Kecamatan Bangli (\%)

c. Pekerjaan Utama Peternak 
Pekerjaan utama masyarakat Desa dengan mayoritas terbanyak yaitu sebagai petani $30 \%$, kemudian diikuti buruh tani $25 \%$, peternak $20 \%$, buruh bangunan $15 \%$, dan pegawai negeri $10 \%$. Rata-rata masyarakat di Desa Tiga memiliki lahan yang dimanfaatkan untuk lahan pertanian dan perkebunan. Lahan pertanian yang cukup luas ditanami bermacam-macam makanan utama dan sayuran seperti padi, jagung, singkong, kol, wortel, terong, cabai, dll. Lahan pertanian yang luas tidak cukup dikerjakan sendiri, sehingga banyak dibutuhkan buruh tani. Sebagian masyarakt juga memiliki lahan yang dimanfaatkan menjadi perkebunan yang ditanami kayu sengon, kayu jati, kemudian di bawahnya dibiarkan untuk tumbuh tanaman liar yang bertujuan untuk pakan ternak. Para petani, buruh tani, buruh bangunan, maupun pehawai negeri ini juga beterenak, tetapi tidak menjadikan usaha ternaknya menjadi pekerjaan utama. Peternak di Desa Tiga tidak menjadikan peternakan sebagai pekerjaan utama karena diketahui untuk mendapatkan keuntungan beternak membutuhkan waktu cukup lama yaitu 6 bulan sampai satu tahun, jika tidak ada kendala berarti.

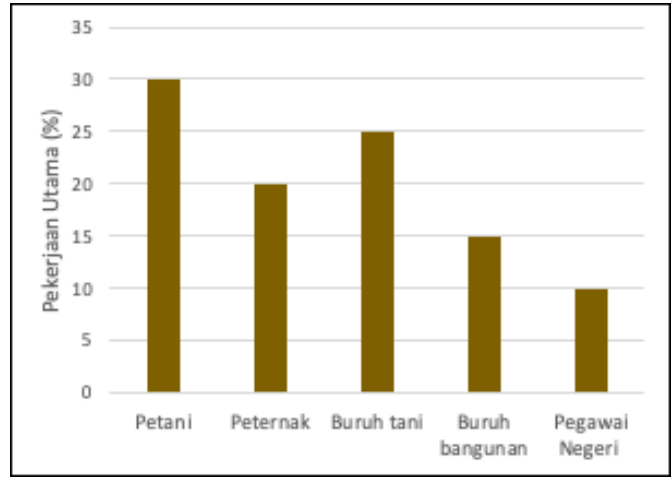

Gambar 3. Pekerjaan utama peternak di Desa Tiga (\%)

\section{d. Pemberian Pakan Ternak}

Tabel 1. Hijauan Pakan Ternak (HPT)

\begin{tabular}{|c|l|l|}
\hline No. & \multicolumn{1}{|c|}{ Nama Indonesia } & \multicolumn{1}{c|}{ Nama Latin } \\
\hline 1 & Rumput gajah & Pennisetum purpureum \\
\hline 2 & Lamtoro & Leucaena leucocephala \\
\hline 3 & Kaliandra & Callandra calothrysus \\
\hline 4 & Gamal & Gliricidia sepium \\
\hline 5 & Tarum & Indigofera tinctoria \\
\hline 6 & Daun tebu & Saccharum officinarum \\
\hline
\end{tabular}

Hijauan Pakan Ternak (HPT) adalah sumber makanan utama ternak ruminansia yang bertujuan untuk memenuhi kebutuhan hidup pokok, produksi, dan berkembang biak. Produksi yang optimal dari ternak ruminansia bergantung pada tersedianya hijauan makanan ternak secara kontinu baik kualitas maupun kuantitasnya, karena lebih dari 70\% $\pm 95 \%$ dari total ransum yang dikonsumsi dalam bentuk hijauan disamping kebutuhan konsentrat [14].

Terdapat 6 jenis HPT yang sering diberikan peternak Desa Tiga pada sapi Bali, yaitu rumput gajah, lamtoro, kaliandra, gamal, tarum, dan daun tebu. Bagi peternak di Desa Tiga mendapatkan HPT di tempat tinggal mereka tidaklah sulit, karena sebagian peternak memiliki lahan pertanian atau perkebunan yang sebagian lokasinya tidak terpakai sehingga dibiarkan ditumbuhi hijauan yang dapat dimanfaatkan untuk pakan ternak. Peternak mencari hijauan setiap hari, yaitu pada pagi dan sore hari. Selain hijauan, peternak juga memberikan konsentrat yang dicampurkan pada air minum sapi yang bertujuan untuk menambah nafsu makan.

\section{e. Luas Kandang Sapi Bali}

Peternak di Desa Tiga merupakan peternak lokal yang hanya memiliki lahan terbatas untuk beternak, sebanyak $60 \%$ peternak memiliki luas kandang $100-200 \mathrm{~m}^{2}$, kemudian $25 \%$ peternak memiliki luas kandang 100 $200 \mathrm{~m}^{2}$, dan $15 \%$ peternak memiliki luas kandang $0-100 \mathrm{~m}^{2}$. Luas kandang disesuaikan jumlah sapi bali yang dimiliki. Luas kandang ini diluar luas kendang ternak yang lain, karena beberapa peternak ada yang memiliki lebih dari satu jenis ternak. Jenis ternak yang dipilih yaitu ayam hias/petarung, ayam potong, bebek, burung, dan babi. Pemilihan ternak tersebut berdasarkan kategori ternak yang cepat dipanen, ketika penjualan sapi sedang turun mereka memiliki cadangan ternak lain, sehingga kestabilan ekonomi terjaga. 
Jurnal Biologi dan Pembelajarannya, Vol 7 No 2, Oktober 2020. Pp: 8-14

e-ISSN: $2406-8659$

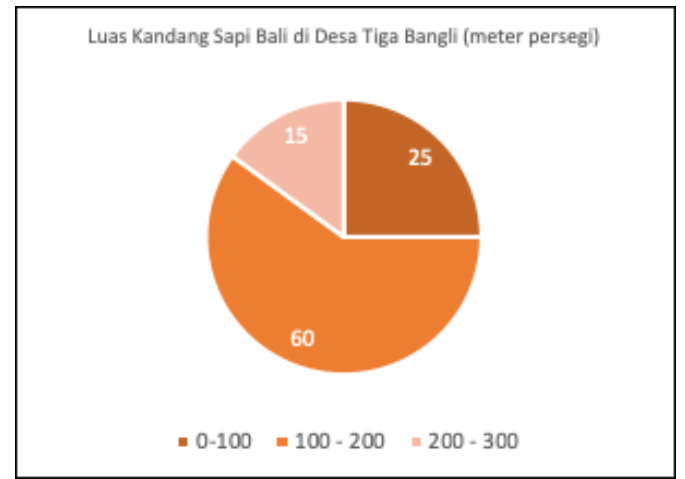

Gambar 4. Luas kandang peternak (\%) di Desa Tiga

Lokasi kandang yang ideal hendaknya terletak cukup jauh dari tempat tinggal atau pemukiman penduduk, biasanya berada di dekat lahan pertanian, di tengah sawah atau ladang [15]. Lokasi kandang juga hendaknya mudah diakses oleh kendaraan agar mudah dalam pemberian pakan dan pengambilannya ketika dijual. Lokasi kandang yang perlu diperhatikan, letaknya harus terpisah dari rumah tinggal dengan jarak minimal 50 meter [16]. Hal ini kurang sesuai dengan peternak di Desa Tiga yang lokasi kandangnya terletak di belakang rumah dengan jarak \pm 0-10 meter. Meskipun kurang sesuai, di Desa Tiga ini bukan merupakan Desa padat penduduk, di sekitarnya masih banyak lahan terbuka seperti lahan pertanian dan kebun, sehingga memiliki sirkulasi udara yang cukup bagus.

\section{Pengaruh Covid-19 bagi Peternak sapi Bali di Desa Tiga}

Rata-rata penjualan sapi Bali di Desa Tiga setiap bulan adalah 3 ekor, biasanya akan mengalami kenaikan secara signifikan ketika Hari Raya Idul Adha, peternak dapat menjual sapi hingga 10 ekor. Setelah adanya pandemi Covid-19 penurunan penjualan tidak terlalu signifikan, peternak dapat menjual sapi 2 ekor setiap bulannya dan tetap mengalami kenaikan pada saat Hari Raya Idul Adha dengan jumlah permintaan hingga 10 ekor (Gambar 5). Permintaan sapi Bali tidak hanya di wilayah Bali, biasanya peternak juga mengirim sapi hingga ke pulau Jawa. Hal ini tentu menjadi peluang ekonomi yang bagus, di saat pemerintah mulai melakukan pengurangan impor sapi, peternak lokal harus memperbanyak produksi agar permintaan dapat dipenuhi oleh peternak lokal. Keadaan di Desa Tiga ini tidak sama dengan peternak dan pedagang hewan kurban di Segoroyoso, Pleret, Bantul, peternak mengakui terjadi penurunan penjualan hingga 30\% dan penurunan konsumsi daging sebanyak $50 \%$ akibat virus Covid-19 [17].

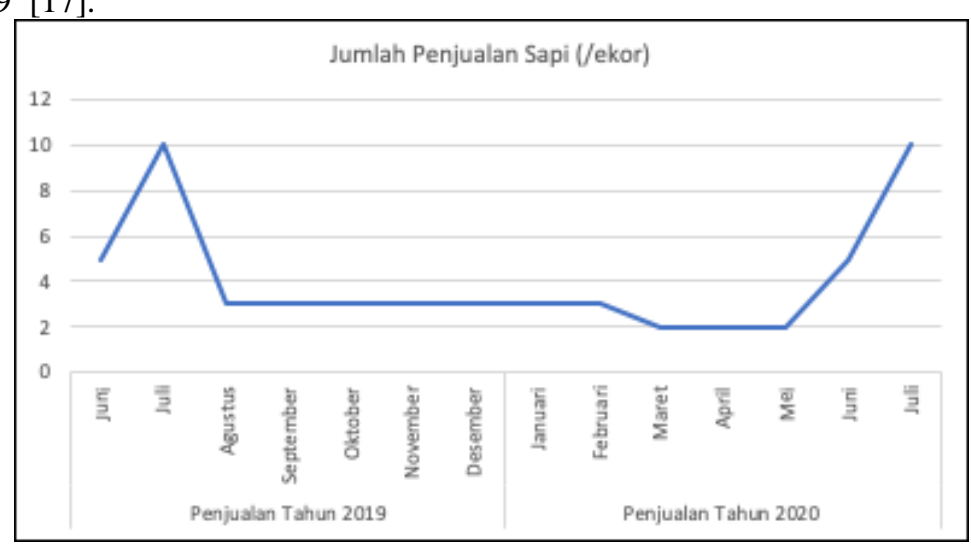

Gambar 5. Jumlah penjualan sapi/hari (ekor) peternak di Desa Tiga

Sebanyak $7 \%$ peternak yang mengetahui bahaya virus Covid-19 dan 19\% peternak mengetahui cara penyebaran virus Covid-19, mengingat jumlah peternak produktif di Desa Tiga ini merupakan usia paruh baya (Gambar 1). Edukasi mengenai bahaya dan penyebaran virus Covid-19 masih perlu digalakan, meskipun virus Covid-19 dapat menginfeksi semua orang tanpa mengenal kelompok usia namun WHO juga menyebutkan bahwa penduduk lanjut usia (lansia), yaitu penduduk usia 60 tahun keatas merupakan kelompok penduduk yang lebih rentan terpapar virus yang banyak menyerang saluran pernafasan ini [18]. Sebanyak $6 \%$ peternak mengetahui gejala awal terpapar virus, $6 \%$ peternak mengetahui cara cuci tangan dengan benar, dan $31 \%$ peternak mengetahui cara memakai masker dan social distancing dapat mencegah penyebaran virus. Beberapa masyarakat sudah paham 
karena sebanyak $31 \%$ telah mendapat edukasi pencegahan penularan virus dari pemerintah/petugas medis, tetapi edukasi ini belum menyerap seluruh masyarakat Desa Tiga. Pemerintah terus melakukan upaya pencegahan, tindakan dan edukasi terkait pandemi Covid-19. Edukasi menjadi hal yang sangat penting untuk membuat masyarakat semakin banyak yang paham dan dapat menerapkan protokol kesehatan untuk pencegahan penularan virus Covid-19.

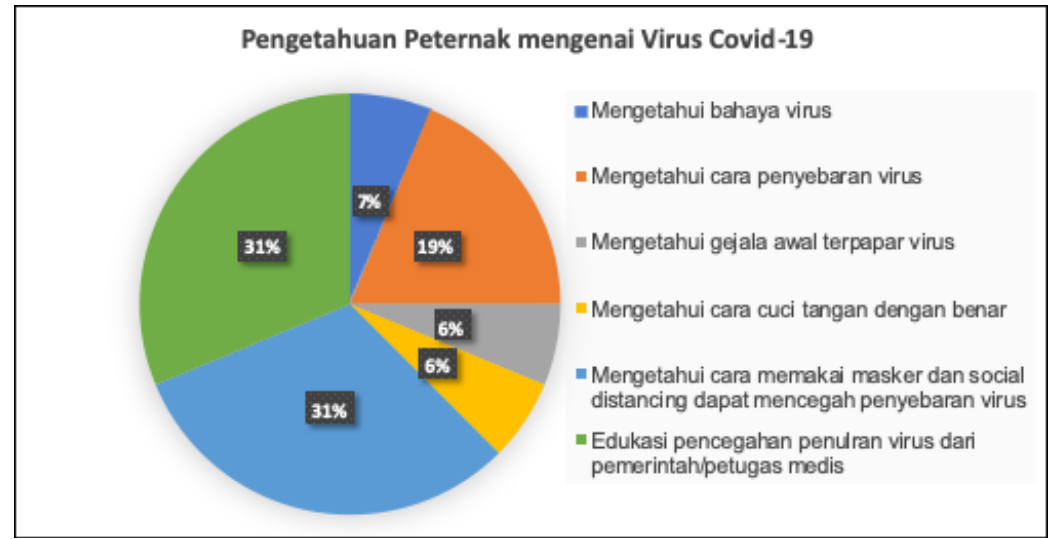

Gambar 6. Pengetahuan Peternak di Desa Tiga mengenai Virus Covid-19

\section{Strategi Pemberdayaan}

Adanya pandemi Covid-19 ini semakin membuka mata masyarakat bahwa usaha peternakan lokal atau skala kecil di pedesaan ini lebih stabil dibandingkan usaha ternak skala besar. Hal ini terjadi karena peternak di Desa Tiga menerapkan konsep beternak berkelanjutan. Strategi pembangunan peternakan dengan cara memproduksi pangan hewani secara berkelanjutan dengan sumber daya alam yang semakin terbatas (lahan, air, keanekaragaman hayati, dan kerusakan lingkungan), diperlukan strategi yang tepat [19]. Peternak di Desa Tiga sangat memperhatikan kondisi lingkungan di sekitarnya, misalnya memanfaatkan kotoran sapi menjadi pupuk alami untuk pertanian, setiap peternak pasti memiliki lahan untuk ditanami beberapa jenis hijauan, mereka juga tidak tertarik untuk menambah jumlah sapi terlalu banyak, jumlah sapi disesuaikan dengan kemampuan mereka dalam kepemilikan kendang dan lahan. Proses perkembangbiakan sapi Bali pun masih secara tradisional, karena menganggap jika kawin suntik menyebabkan sapi produktivitas menurun. Rata-rata dalam satu kelompok ternak memiliki satu sapi jantan yang unggul sehingga dapat dikawinkan dengan beberapa sapi betina, hal yang perlu diperhatikan peternak perlu diedukasi cara meminimalisasi terjadinya perkawinan sedarah atau inbreeding. Strategi pemberdayaan bagi peternak di era pandemi Covid-19 ini perlu dilakukan yaitu diberikannya edukasi tentang bahaya Covid-19 serta protokol kesehatan untuk pencegahan penularan virus Covid-19. Hal ini bertujuan agar semua peternak di Desa Tiga terhindar dari virus Covid-19 sehingga produktifitas dalam menghasilkan sapi Bali tetap terjaga, mengingat sapi Bali termasuk dalam sapi lokal yang jumlah populasinya terbatas.

Pemerintah Provinsi Bali sebaiknya lebih memperhatikan kesejahteraan peternak, seperti mengadakan edukasi mengenai kawin suntik atau inseminasi buatan, vaksin gratis, perawatan, luas, dan lokasi kandang sesuai standar, edukasi jenis pakan hijauan dan pakan pendamping ternak/kosentrat yang cocok untuk sapi Bali, dan penyediaan rumah potong hewan di Kabupaten Bangli. Saat ini rumah potong di Bangli belum ada, biasanya peternak harus menjual sapi mereka ke Kabupaten Gianyar. Kerja sama yang baik antara peternak dan pemerintah Provinsi Bali diharapkan menjadi salah satu langkah konservasi dan perbaikan mutu genetik sapi Bali, sehingga menciptakan kesejahteraan peternak yang terintegrasi dan berkelanjutan.

\section{SIMPULAN}

Kesimpulan dari penelitian ini menunjukkan bahwa adanya pandemi Covid-19 bagi usaha peternakan lokal atau skala kecil di pedesaan lebih stabil dibandingkan usaha ternak skala besar. Keadaan sosial dan ekonomi petenak tidak berpengaruh secara signifikan. Strategi pemberdayaan bagi peternak yaitu perlu adanya edukasi tentang bahaya dan protokol kesehatan untuk pencegahan penularan virus Covid-19. Pemerintah Provinsi Bali sebaiknya lebih memperhatikan kesejahteraan peternak, seperti pemberian edukasi kawin suntik atau inseminasi buatan, vaksin gratis, perawatan kandang sesuai standar, jenis pakan hijauan dan kosentrat yang cocok untuk sapi Bali, dan penyediaan rumah potong hewan di Kabupaten Bangli. Kerja sama yang baik antara peternak dan pemerintah Provinsi Bali diharapkan menjadi salah satu langkah konservasi dan perbaikan mutu genetik sapi Bali, sehingga menciptakan kesejahteraan peternak yang terintegrasi dan berkelanjutan. 
Jurnal Biologi dan Pembelajarannya, Vol 7 No 2, Oktober 2020. Pp: 8-14

e-ISSN: $2406-8659$

\section{UCAPAN TERIMA KASIH}

\section{DAFTAR PUSTAKA}

[1] Nadia. 2020. Dinamika Industri Sapi Potong di Masa Pandemi Covid-19. https://fapet.ugm.ac.id/id/dinamika-industri-sapi-potong-di-masa-pandemi-covid-19-2/ (diakses 18 September 2020).

[2] Komisi Ilmu Pengatahuan Dasar Akademi Ilmu Pengetahuan Indonesia (KIPDAIPI). Fakultas Kedokteran Hewan IPB dan Pusat Penelitian Biologi LIPI. 2012. Seminar Nasional Konservasi dan Pemanfaatan Plasma Nutfah Satwa Nusantara. Bogor.

[3] Daryanto, A. 2011. Peranan Modal Sosial dalam Pembangunan Peternakan. Trobos Edisi Januari 2011. Bandung.

[4] Pasar Dana. 2020. Kementan Sebut Tren Impor Sapi Alami Penurunan 30 Persen. Pasar Dana. Jakarta. https://pasardana.id/news/2020/7/15/kementan-sebut-tren-impor-sapi-alami-penurunan-30persen/ (diakses 16 September 2020).

[5] Abidin. Z. 2002. Penggemukan Sapi Potong. Jakarta: PT. Agro Media Pustaka.

[6] Ramadhani, Mutia dan D. Murdaningsih. 2015. Bangli Jadi Sentral Baru Peternakan Sapi Bali. https://www.republika.co.id/berita/ekonomi/makro/15/02/12/njn7o8-bangli-jadi-sentral-barupeternakan-sapi-bali (diakses 17 September 2020).

[7] Forum Desa Tiga Membangun. 2015. Potensi Desa Bidang Peternakan. https://desatiga.wordpress.com/potensidesa/ (diakses 16 September 2020).

[8] Forum Desa Tiga Membangun. 2015. Banjar Buungan. https://desatiga.wordpress.com/banjar/banjar-buungan/ (diakses 16 September 2020).

[9] Singarimbun, M dan Effendi, S. 1989. Metode Penelitian Survei. Cetakan Kedua. LP3S. Jakarta.

[10] Hodgetts, D. J., \& Stolte, O. M. E. 2012. Case-based research in community and social pychology: Introduction to the special issue. Journal of Community \& Applied Social Psychology 22(1):379389.

[11] N. Supartini dam H. Darmawan. 2012. Strategi Pemberdayaan Peternak Dalam Usaha Konservasi Sapi Jawi Pandaan Di Kecamatan Prigen Kabupaten Pasuruan. Buana Sains 12(2):27-34.

[12] Wasito, H. R. 2005. Peternakan Harus Jadi Unggulan. Penerbit Permata Wacana Lestari. Jakarta.

[13] Mastuti dan Hidayat. 2008. Peranan Tenaga Kerja Perempuan dalam Usaha Ternak Sapi Perah di Kabupaten Banyumas (Role of Women Workers at Dairy Farms in Banyumas District) Fakultas Peternakan Universitas Jenderal Soedirman, Purwokerto.

[14] Susetyo, S., 1980. Padang Pengembalaan. Fakultas Peternakan IPB. Bogor.

[15] Nugraha, K. H., Sudodo, \& Hutagalung, R. A. 2009. Hubungan Antara Persepsi Masyarakat tentang Ruang Terbuka Hijau dan Etika Lingkungan dengan Partisipasi Masyarakat Pengembangan Kota Berwawasan Lingkungan. Lingkungan Hidup 1(1):1-12.

[16] Sihombing, D. T. H.2000. Teknik Pengolahan Limbah Kegiatan/Usaha Peternakan. Pusat Penelitian Lingkungan Hidup Lembaga Penelitian Institut Pertanian Bogor.

[17] Dinnata, Regi Y.W. 2020. Terdampak Pandemi, Penjualan Sapi untuk Idul Adha Turun 30 Persen. https://ayoyogya.com/read/2020/07/06/39766/terdampak-pandemi-penjualan-sapi-untuk-iduladhaturun-30-persen (diakses tanggal 18 September 2020).

[18] Pusat Penelitian Kependudukan LIPI. 2020. Lansia dalam Situasi Pandemi COVID-19. https://kependudukan.lipi.go.id/id/berita/53-mencatatcovid19/847-lansia-dalam-situasi-pandemi-covid$\underline{19}$ (diakses 17 September 2020).

[19] Bahri, S. dan B. Tiesnamurti. 2012. Strategi Pembangunan Peternakan Berkelanjutan dengan Memanfaatkan Sumber Daya Lokal. Jurnal Litbang Pertanian 31(4):142-152. 